\title{
Geoarchaeological evidence of Holocene human impact and soil erosion on a till plain in Vorpommern [Kühlenhagen, NE-Germany]
}

\author{
Mathias Küster, Fred Ruchhöft, Sebastian Lorenz, Wolfgang Janke
}

\begin{abstract}
:
Geoarchaeological investigations close to a glacigenic kettle-hole provide evidence of human impact on a till plain in Vorpommern in prehistorical and historical times and its geomorphic response. Basal sedimentary fillings of the investigated depression comprise peat, gyttja and aggradational peat reflecting Early to Mid-Holocene hydrological changes. The upper sequence of alternating colluvial and organic layers indicate varying human impact over time. Absolute AMS ${ }^{14} \mathrm{C}$-datings of buried peats and mineral horizons with partly high organic matter contents, proven by palynological and archaeological data, reflect interim phases of surface stability. In contrast, the colluvial sands reflect phases of accelerated prehistorical and historical settlement and land use. The sands can be dated relatively to the organic layers as well as linked to the adjacent archaeological finds. The increased erosion processes can thusly be placed during the Late Neolithic Period, the transition from the Late Bronze Age to Early Iron Age, the Medieval Period and finally during the Modern Era. Accumulation of the youngest colluvium leads finally to the filling of the outer portions of the kettle-hole up to the current surface.
\end{abstract}

[Geoarchäologischer Nachweis des holozänen menschlichen Einflusses und Bodenerosion auf einer Grundmoränenplatte in Vorpommern [NE-Deutschland]]

Kurzfassung

Geoarchäologische Untersuchungen im Bereich eines glazigenen Solls verweisen auf den holozänen menschlichen Einfluss auf einer Grundmoränenplatte in Vorpommern in prähistorischer und historischer Zeit sowie dessen geomorphologische Rückkopplung. Die basale sedimentäre Füllung der untersuchten Depression besteht aus Torf, Mudde und Verlandungstorf und spiegelt früh- bis mittelholozäne hydrologische Schwankungen wider. Die obere Sequenz von wechselnden Kolluvien und organogenen Schichten deutet auf einen variierenden menschlichen Einfluss im Laufe der Zeit hin. Absolute AMS ${ }^{14} \mathrm{C}-\mathrm{Datierungen}$ von begrabenen Torfen und Mineralbodenhorizonten mit zum Teil erhöhten Anteilen organischer Substanz, abgesichert durch palynologische und archäologische Daten, belegen zwischenzeitliche Phasen von Oberflächenstabilität. Hingegen reflektieren die kolluvialen Sande Phasen erhöhter prähistorischer und historischer Besiedlung und Landnutzung. Die Sande können zum einen relativ durch die organogenen Schichten datiert und zum anderen zu den benachbarten archäologischen Funden in Beziehung gebracht werden. Erhöhte Erosionsprozesse werden demnach in das späte Neolithikum, den Übergang späte Bronzezeit zur frühen Eisenzeit, das Mittelalter und letztendlich in die Moderne gestellt. Die Akkumulation des jüngsten Kolluviums führt im Randbereich des Solls zur völligen Verfüllung bis an die rezente Oberfläche.

Keywords:

till plain, soil erosion, Vorpommern, kettle-hole, Holocene, human impact

Addresses of authors: M. Küster, S. Lorenz, W. Janke, University of Greifswald, Institute of Geography and Geology, Friedrich-Ludwig-Jahn-Str. 16, 17487 Greifswald, Germany. E-Mail: mathias.kuester@uni-greifswald.de; F. Ruchhöft, University of Greifswald, Institute of History, Hans-Fallada-Str. 1, 17487 Greifswald, Germany. E-Mail: fred.ruchhoeft@uni-greifswald.de

\section{Introduction}

Investigations of past human impact on terrestrial environments in Central Europe have been well established by the geosciences over the last five decades. Studies often focus on soil erosion processes, which are anthropogenically induced and triggered by geological forces (BORK et al. 1998; DotTERWEICH 2005; STARKEL 2005). In contrast to the low mountain ranges, erosion processes within the lowlands of NE-Germany occur preferentially along the transitional zone of landscape components (AMELANG, JANKE \& KLIEWE 1983). In the range of till plains in Vorpommern, colluvial slope deposits are predominant. Accumulation occurs within river catchments, kettle-holes and other wet depressions (KaISER \& JANKe 1998; Helbig et al. 2002). The formation of colluvial sediments is closely related to the Holocene settlement and land use history. Anthropogenic impacts differ in time and space, so colluviation is evident during different periods and in different accumulation areas (NILlER 1998). Qualitative comparisons of regional records offer an appropriate instrument for deducing a spatiotemporal model of erosion processes und human impact on a local, regional and global scale (BORK 1983; BORK et al. 1998; Bork 2006; DotTerweich 2008; Dreibrodt et al. 2010). Regional refinements of these general models are important to detect diachronisms due to differences in land use, vegetation and relief development as well as climate (Wilkinson 2003; ReIß et al. 2009). For a good understanding of human impact in the past, it is therefore important to blend geoscientific records and archaeological findings into a geoarchaeological context, providing a comprehensive palaeo-perspective of environmental history (KALIs, Merkt \& Wunderlich 2003; ZolitschKa, Behre \& SCHNEIDER 2003). The Kühlenhagen site reveals new data concerning land use history, settlement pattern and the landscape's geomorphological response, as an example for till plain sites in Vorpommern (NE-Germany). 


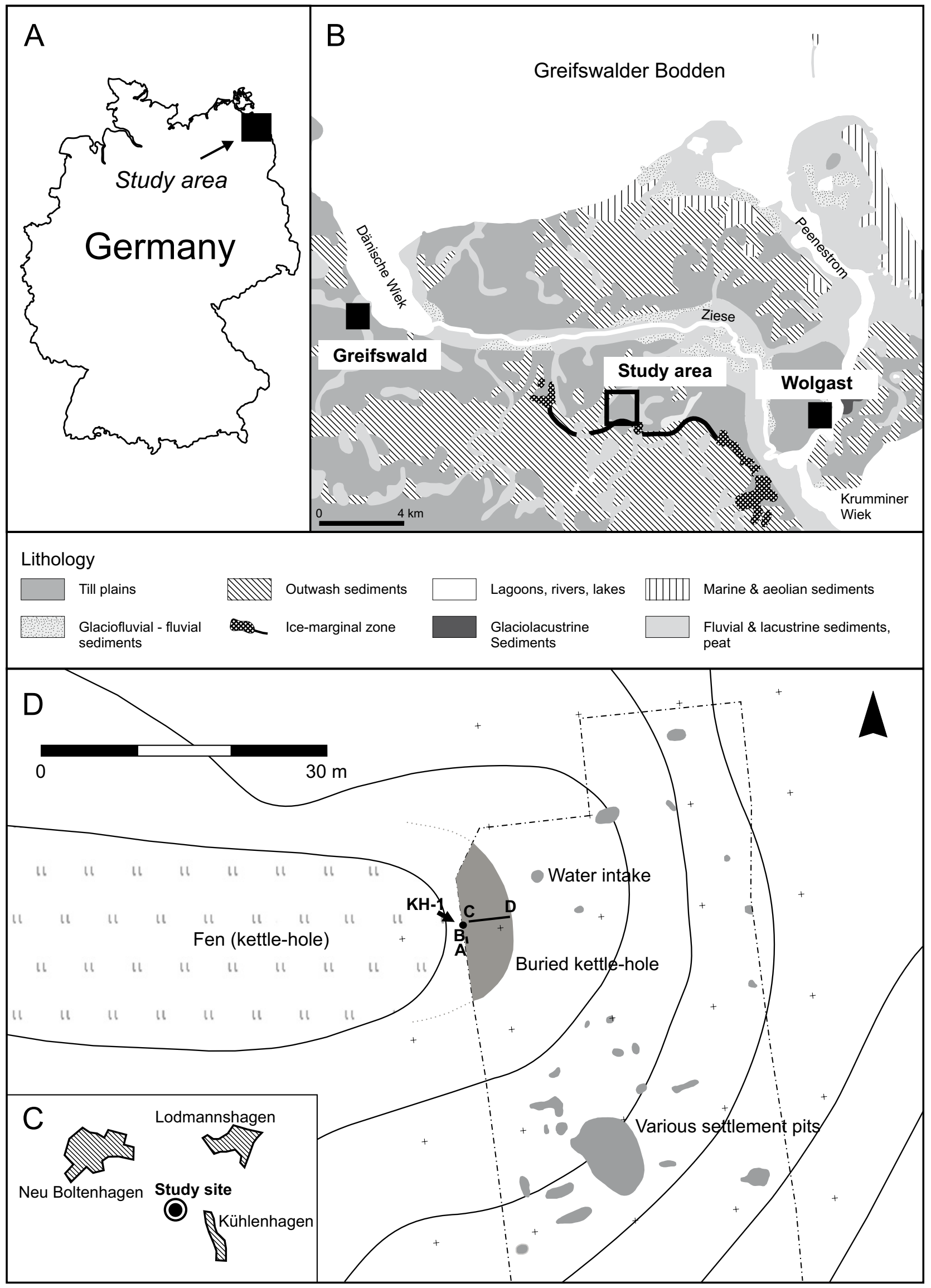

Fig. 1: Location of the study area in Germany (A). The geological situation of the young morainic landscape around the study site in NE-Germany (B; GLA 1996). Geoarchaeological fieldwork took place in the NW of the village Kühlenhagen (C). The archaeological section in the range of the partly buried kettle-hole (D). The investigated exposures $(A-B, C-D)$ and reference core KH-1 are described in detail in Fig. 2.

Abb. 1: Lage des Untersuchungsgebietes in Deutschland (A). Die geologische Situation der fungmoränenlandschaft in der Umgebung des Untersuchungspunktes in NE-Deutschland (B; GLA 1996). Die geoarchäologischen Untersuchungen fanden im Nordwesten der Ortschaft Kühlenhagen statt (C). Der archäologische Schnitt im Bereich des teilweise begrabenen Solls (D). Die untersuchten Aufschlüsse (A-B, C-D) und der Referenzkern KH-1 werden näher in $A b b .2$ beschrieben. 


\section{Study area}

The investigation area is characterised by flat and undulating till interlocked with outwash plains and transected by river valleys, mainly formed during the Mecklenburgian Phase of the Weichselian glaciation (RüHBERG et al. 1995, Fig. 1). Periglacial processes during the Late Glacial resulted in cryogenic destratification of glacigenic surface sediments, sedimentation processes on plain sites including formation of "Geschiebedecksand" (GDS, "cover sands") and cryogenic sediment structures such as ice-wedges. Nival runoff, solifluction and abluation cause sediment runoff along slopes, resulting in a markable reshaping of glacigenic topography (Helbig 1999; KLIEwE 2004). River valleys supplemented by tributary valleys (periglacial dry valleys) display major regional differences in elevation of 10-30 $\mathrm{m}$ to the adjacent plain sites (JANKE 1983), representing the base level of Holocene erosion processes. As a result of dead ice melting, till plains are apparelled by small basins like glacigenic kettle-holes, and furthermore wet or dry depressions of anthropogenic origin (JANKE \& JANKE 1970; KLAFS, JeschKe \& SCHMIDT 1973).

The Kühlenhagen site is located on the edge of a till plain between the towns Greifswald and Wolgast south towards the Ziese Valley, with elevations of 16-30 $\mathrm{m}$ a.s.l. (Fig. 1). The further surroundings are currently used by forestry and agriculture.

\section{Material and Methods}

\section{Field work}

In preperation for the construction of the OPAL gas pipeline, archaeological investigations took place at the Kühlenhagen site in August 2009. The OPAL is the southern terrestrial connection to the subaquatic Nordstream pipeline from Russia to Central Europe through the Baltic Sea. The investigated section at Kühlenhagen of c. 4000 sqm was divided into grids of $10 \mathrm{~m} \mathrm{x} 10 \mathrm{~m}$. All findings of each grid were marked, the exact location noted and recovered. Finds were described and classified in regional archaeological phases according to ENDTMANN (2004). At the transition zone of the till plain and an aggradated and marginally filled depression a cross-section was excavated (Fig. 2). The reference faces were cleaned and described after excavation following the guidelines of the IUSS WORKING GrouP WRB (2006). The exposure was documented in photographs and a scaled drawing. For detailed laboratory analysis a sediment core of $8 \mathrm{~cm}$ diameter was recovered close to the cross-section to a depth of $2 \mathrm{~m}$ (KH-1, Fig. 1).
Laboratory methods

Dry-bulk-density (DBD) and water content were calculated after sample drying at $105^{\circ} \mathrm{C}$ based on $4 \mathrm{ml}$ sample cylinder at $5 \mathrm{~cm}$ steps. The organic content was determined by loss on ignition (LOI) at $550^{\circ} \mathrm{C}$ for 2 hours. Afterwards carbonates were removed by $(10 \%) \mathrm{HCl}$ (organic carbon was removed by burning process) for grain-size analysis with a laser particle sizer (Fritsch-Analysette 22). Pollen samples from a buried soil surface horizon (Ahb, IUSS WORKING Group WRB 2006) as an age proof for AMS ${ }^{14} \mathrm{C}$-dates were extracted in $1 \mathrm{~cm}$ slices from the core and separated by acetholyses (BEUG 2004). Non-arboreal pollen (NAP, spores and algae) were related to the amount of 100 tree pollen. Pollen zones (PZ) are related to Firbas (1949) and KAISER et al. (2002). Four radiocarbon datings were determined at organic layers, comprising macrofossil remains from peat and one bulk sample of a mineral horizon rich in organic matter were determined (Tab. 1). Dates were calibrated using CALIB 5.0.1 (Stuiver, Reimer \& Reimer 2005).

\section{Results}

Archaeological finds and settlements

Field investigations yielded 50 finds comprising a typical settlement repertory. Most of them were hardly damaged or moderately preserved, but some of them were significant and gave the opportunity to date the settlement site.

The mapped pits were used for storage purpose, others were mine pits. Adjacent to the pits seven fire places and one oven were documented. Almost $100 \mathrm{~m}$ south of the depression four post-holes were found indicating the remains of a double-span house. House types like this $(20 \mathrm{~m}$ long, $6 \mathrm{~m}$ wide) are well documented in Late Bronze Age/Early Iron Age settlement sites in NE-Germany (ScHMIDT 2006).

Some meters beside the investigated depression a water intake was found (Fig. 1). The round pit has an average depth of $1 \mathrm{~m}$ and is filled with loamy sands rich in organic matter at the bottom and loamy sands at the top, comprising several fragments of pottery and charcoal. The adjacent sandy till sediments are characterised by stagnic features.

Pottery from the settlement belongs to funnel rim vessels or vessels with bulbous body and slightly grooved rim. Another typical type of ceramic for the site are baking plates. This kind of ceramics is also described in other study sites in NE-Germany, typical for the transition Late Bronze Age to the Early Iron Age (SchoKnecht 1978). It is especially significant for the "Usedom-Wolin-Group", a cultural group of the Early Iron Age in the area around the mouth of the Oder River, at the very northern rim of the Lusatian

Tab. 1: Results of the AMS-dating of buried peats and humic sand samples. * Dates were calibrated using CALIB 5.0.1 (STUIVER, REIMER \& REIMER 2005).

Tab. 1: Ergebnisse der AMS-Datierungen von Proben aus begrabenen Torfen und Anmoor. * Die Daten wurden unter Verwendung von CALIB 5.0.1 (STUIVER, REIMER \& REIMER 2005) kalibriert.

\begin{tabular}{|c|c|c|c|c|c|c|}
\hline Core & Depth $[\mathrm{cm}]$ & ${ }^{14} \mathrm{C}$ yr BP & Calibrated age $[2 \sigma]^{*}$ & Material & $\delta^{13} \mathrm{C}$ & Laboratory ID \\
\hline $\mathrm{KH}-1$ & $90-91$ & $1699 \pm 41$ & $245-421 \mathrm{AD}$ & humic sand & -29.4 & Erl-13813 \\
\hline $\mathrm{KH}-1$ & $115-116$ & $2869 \pm 42$ & $1133-919$ BC & peat & -30.3 & Erl-13814 \\
\hline $\mathrm{KH}-1$ & $162-163$ & $9153 \pm 62$ & 8495-8271 BC & peat & -29.5 & Erl-13815 \\
\hline $\mathrm{KH}-1$ & $187-188$ & $8876 \pm 61$ & 8238-7792 BC & peat & -28.3 & Erl-13816 \\
\hline
\end{tabular}


A

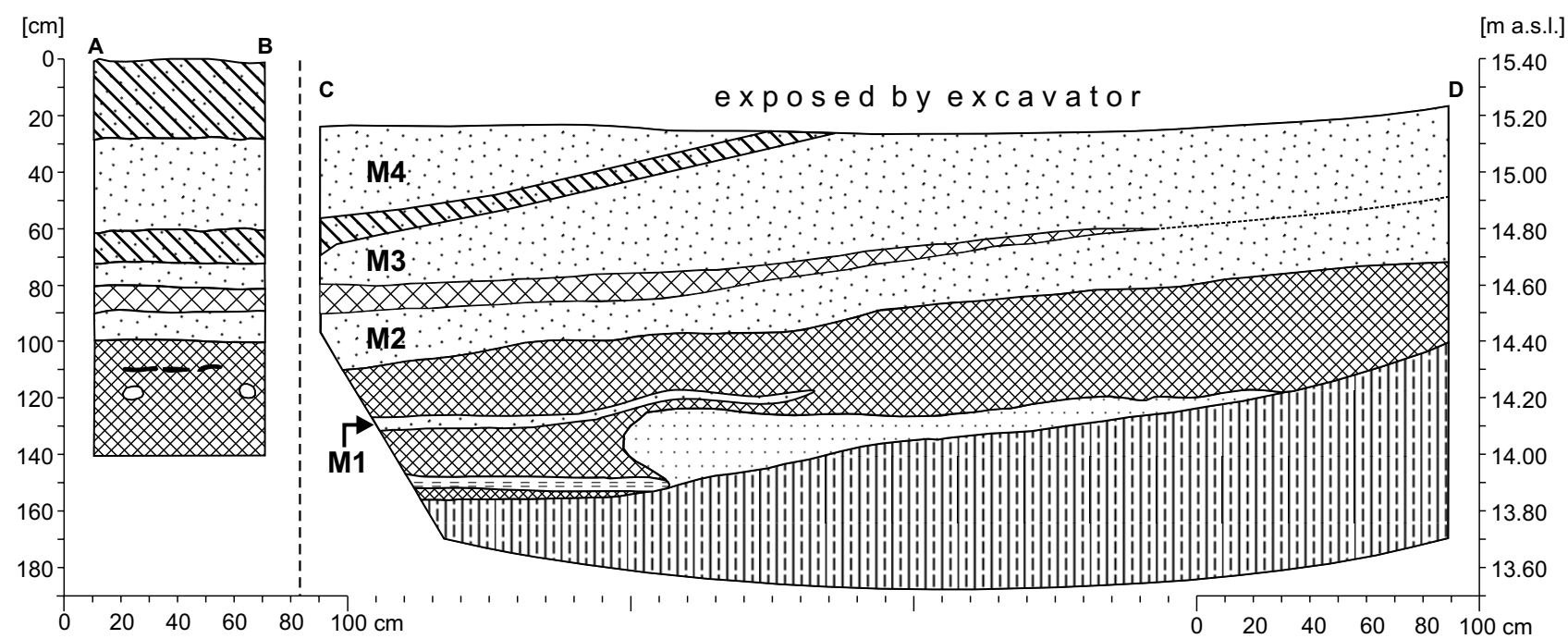

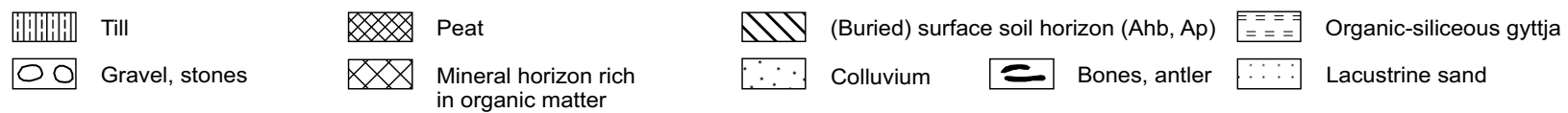

B

Core $\mathrm{KH}-1$

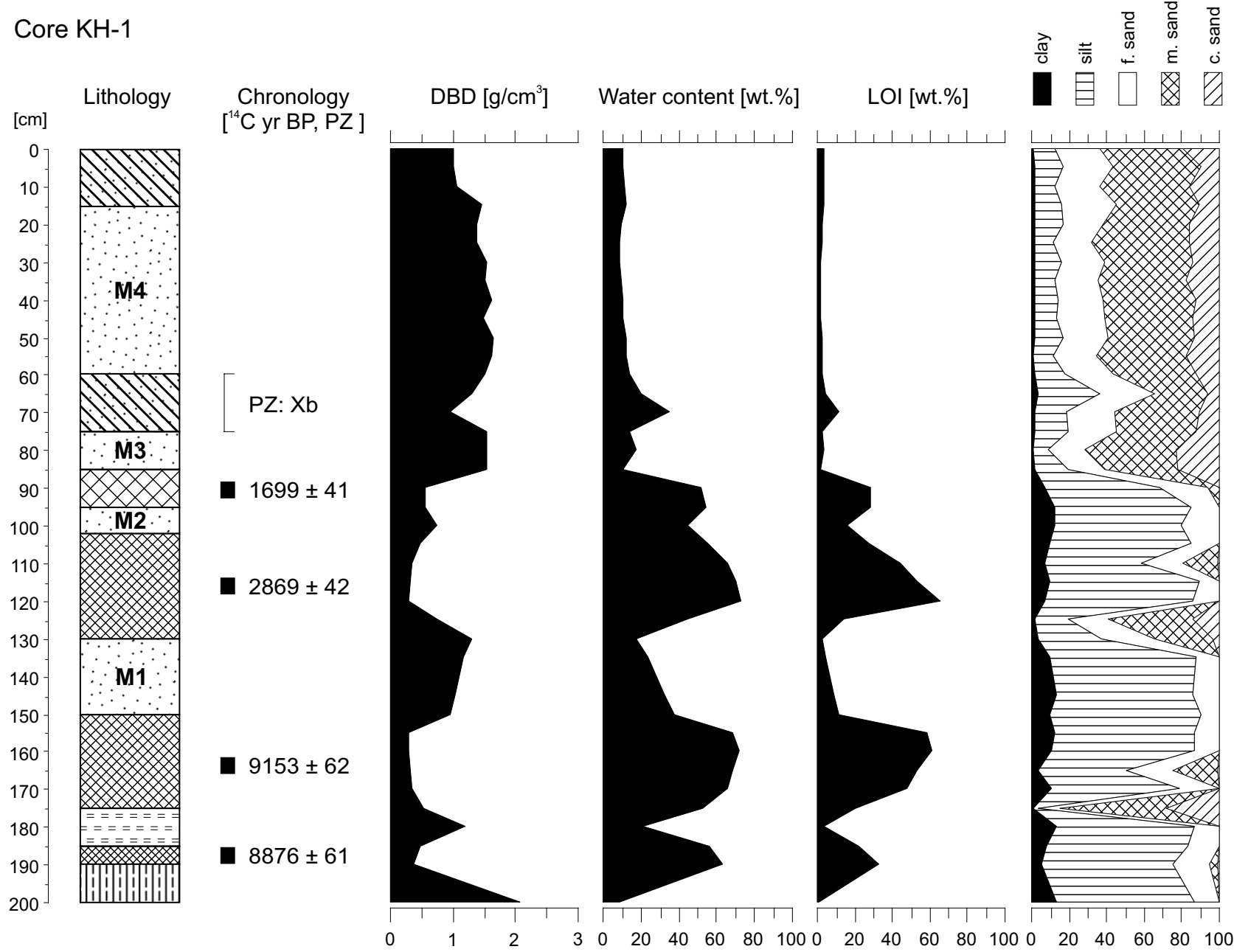

Fig. 2: Detailed drawing of the lithological compositon of the kettle-hole in its margin (A). Lithology, chronology and sedimentary parameters of core KH-1 (B). Abb. 2: Detaillierte Zeichnung der lithologischen Zusammensetzung im Randbereich des Solls (A). Lithologie, Chronologie und sedimentologische Parameter des Kerns $\mathrm{KH}-1$ (B). 
culture, described by HoRst (1963) and LAMPE (1981, 1989). Another sign for dating the settlement to this time is the lack of flint artefacts, which are distinctive for the Early Bronze Age (Szczesiak 1999).

\section{Sedimentary and palynological records}

The basin of the depression is made up of a greyish-blue diamicton, which shows a dominant fine sediment matrix of silt and clay with subordinated gravel and stones (Fig. 2). Stratigraphically it can be classified as glacigenic till asso- ciated with the Mecklenburgian Phase of the Weichselian glaciation.

The thin sandy peat layer above is characterised by LOI of c. $32 \%$. A peat sample reveals a radiocarbon age of $8876 \pm 61 \mathrm{yr}$ BP (Tab. 1) and dates the onset of peat formation to the Early Boreal. The absence of thermophilic pollen species and the high abundance of Betula, NAP and the total amount of pollen and spores $/ \mathrm{mm}^{3}$ indicate a Preboreal palyno-age of that peat (Tab. 2, $187 \mathrm{~cm}$ depth).

The coarse detrital gyttja above reflects a rising trend of

Tab. 2: Selected parameters of the palynological analyses of organic layer and the Ahb horizon. * SA - Subatlantic, AT - Atlantic, AT/SB - Atlantic/Subboreal, $P B$ - Preboreal.

Tab. 2: Ausgewählte Parameter der pollenkundlichen Analysen der organischen Horizonte und des fossilen Bodenhorizontes, fAh. ${ }^{*} S A-S u b a t l a n t i k u m, ~ A T$ - Atlantikum, AT/SB - Atlantikum/Subboreal, PB - Präboreal.

\begin{tabular}{|c|c|c|c|c|c|c|c|}
\hline Depth [cm] & 67 & 69 & 71 & 73 & 164 & 174 & 187 \\
\hline AP [\%] & 59.2 & 51.8 & 64.2 & 58.6 & 81.9 & 94.0 & 73.7 \\
\hline Shrubs [\%] & 1.8 & 4.7 & 0.6 & 1.2 & 5.5 & 3.2 & 5.1 \\
\hline $\operatorname{NAP}[\%]$ & 39.0 & 43.5 & 35.2 & 40.2 & 12.6 & 2.8 & 21.2 \\
\hline Pinus & 19.0 & 21.0 & 21.5 & 50.2 & 39.3 & 71.1 & 39.6 \\
\hline Betula & 3.0 & 8.0 & 2.0 & 3.0 & 13.5 & 3.4 & 41.6 \\
\hline Fagus & & & & 1.0 & & & \\
\hline Quercus & 8.0 & 9.0 & 6.0 & 7.0 & 12.5 & 4.9 & \\
\hline Tilia & & 3.0 & & & 6.7 & 7.4 & \\
\hline Ulmus & 1.0 & & 1.0 & & 1.0 & 0.5 & 2.0 \\
\hline Alnus & 3.0 & 9.0 & 5.0 & 10.0 & 22.0 & 11.3 & 1.0 \\
\hline Salix & 66.0 & 50.0 & 64.5 & 28.8 & 4.0 & 1.5 & 15.8 \\
\hline Corylus & 3.0 & 8.0 & 1.0 & 2.0 & 6.0 & 2.5 & 1.0 \\
\hline Juniperus & & 1.0 & & & & & 6.0 \\
\hline Wild grasses [undiff.] & 5.0 & 6.0 & 17.0 & 12.0 & 4.8 & 1.0 & 5.0 \\
\hline Cyperaceae & 7.0 & 16.0 & 8.0 & 6.0 & 3.9 & 3.0 & 20.0 \\
\hline Cereals [sine Secale] & 5.0 & 3.0 & 3.0 & 12.0 & & & \\
\hline Secale & 6.0 & 4.0 & 1.0 & 15.0 & & & \\
\hline Cultural indicators/Weeds & 13.0 & 12.0 & 4.0 & 7.0 & 2.0 & & \\
\hline Artemisia sp. & 1.0 & 2.0 & 1.0 & 1.0 & 1.0 & & 1.0 \\
\hline Chenopodiaceae & & 1.0 & 1.0 & 2.0 & & & \\
\hline Plantago lanceolata & 2.0 & 3.0 & & & 1.0 & & \\
\hline Centaurea cyanus & 5.0 & 4.0 & 1.0 & 4.0 & & & \\
\hline Calluna vulgaris & 3.0 & 4.0 & 1.0 & 2.0 & & & \\
\hline Aster-Type & 1.0 & & & 1.0 & 1.0 & & \\
\hline Fenestrate Compositae & 25.0 & 34.0 & 17.0 & 6.0 & & & \\
\hline Filipendula ulmaria & 2.0 & & & 3.0 & & 0.5 & 1.0 \\
\hline Apiaceae & 1.0 & 2.0 & & 2.0 & & & 1.0 \\
\hline Typha latifolia & & & & & 2.0 & 0.5 & \\
\hline Sphagnum-Type & & 6.0 & 2.0 & 1.0 & & & 2.0 \\
\hline Bryophyta-Type [sine Sphagnum] & 34.0 & 100.0 & 38.0 & 28.0 & 64.0 & 70.0 & 16.0 \\
\hline Monolete Polypodiales & 9.0 & 9.0 & 6.0 & 8.0 & 26.0 & 52.0 & 2.0 \\
\hline Pteridium aquilinum & 2.0 & 1.0 & 2.0 & 2.0 & 2.0 & & \\
\hline Lycopodium inundatum & 16.0 & 41.0 & 30.0 & 6.0 & & & 1.0 \\
\hline Equisetum-Type & 11.0 & 14.0 & 8.0 & 4.0 & 6.7 & 5.0 & 22.0 \\
\hline Radiococcus nimbatus-Type & & 1.0 & & & & & 3.0 \\
\hline Pediastrum sp. & & & & & & & 2.0 \\
\hline Botryococcus braunii & & & & & & 1.0 & 1.0 \\
\hline Pollen+Spores $/ \mathrm{mm}^{3}$ sediment & 4.0 & 4.9 & 14.2 & 342.6 & 435.2 & 1463.0 & 87.6 \\
\hline Pollen zones [FIRBAS 1949, KaISER et al. 2002] & $\mathrm{Xb}$ & $\mathrm{Xb}$ & $\mathrm{Xb}$ & $\mathrm{Xb}$ & $\mathrm{VII} / \mathrm{VIII}$ & $\mathrm{VI}$ & IV \\
\hline Chronozones [MAngerud et al. 1974] & SA & SA & SA & $\mathrm{SA}^{*}$ & AT/SB* & $\mathrm{AT}^{*}$ & $\mathrm{~PB}^{*}$ \\
\hline
\end{tabular}




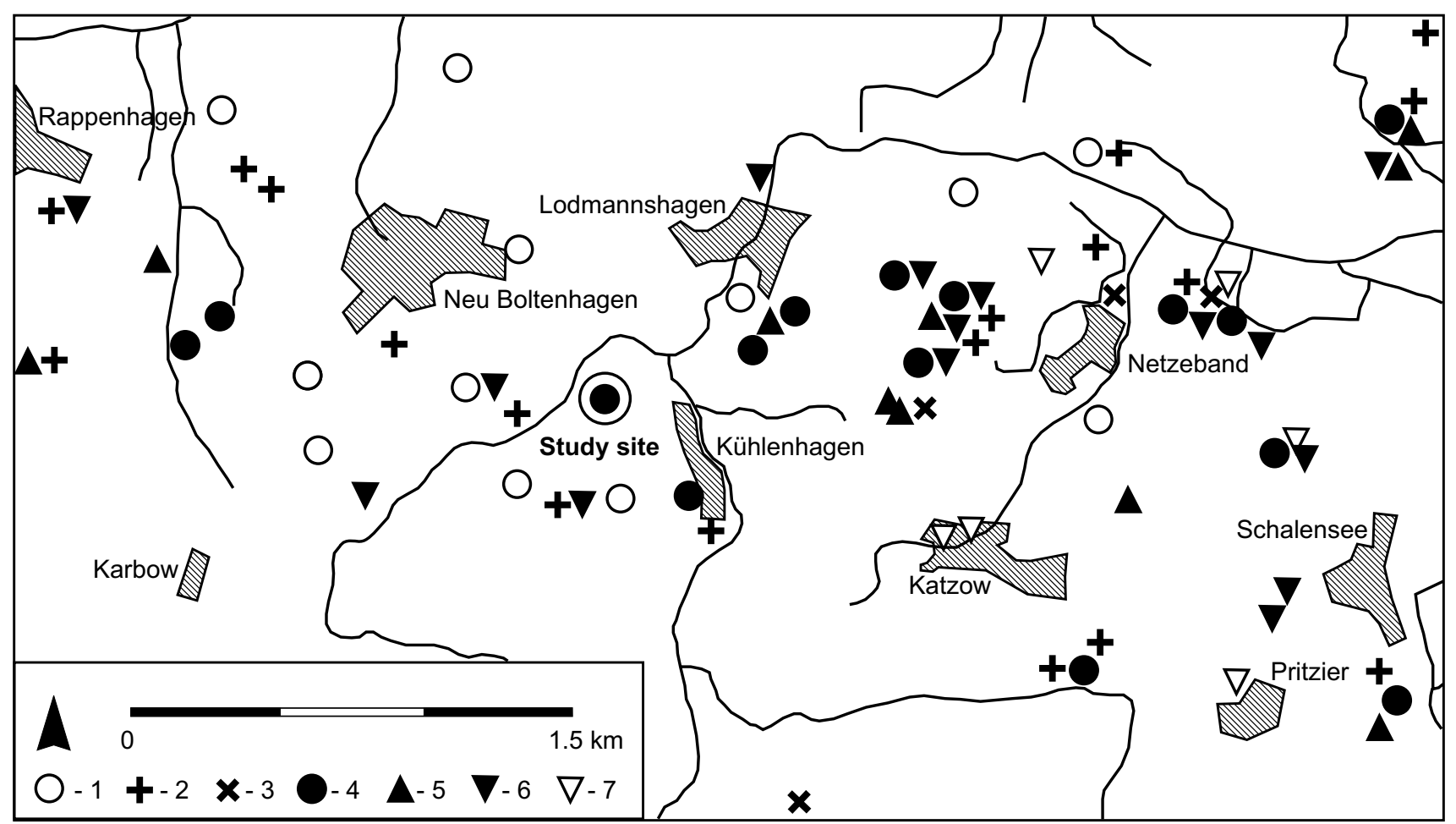

Fig. 3: Prehistorical finds and settlements around Kühlenhagen. 1 Pre-Neolithic undiff., 2 Neolithic, 3 Early Bronze Age, 4 Late Bronze Age, 5 Pre-Roman Iron Age, 6 Roman Empire, 7 Iron smelting.

Abb. 3: Prähistorische Funde und Siedlungen um Kühlenhagen. 1 vorneolithisch undiff., 2 Neolithikum, 3 frühe Bronzezeit, 4 späte Bronzezeit, 5 Vorrömische Eisenzeit, 6 Römische Kaiserzeit, 7 Eisenverhüttung.

water table resulting in sedimentation of lacustrine sediments within the depression. In the same stratigraphic position with an off-set of almost $2 \mathrm{~m}$ to the organic gyttja detected in core $\mathrm{KH}-1$ and exposure $\mathrm{KH}-2$ (C-D) a calcareous gyttja was identified during excavation. Thus, one can assume the intermediate existence of a small lake including alternating littoral sedimentation conditions on a small scale. In the shallow fringe wave effects of an open water body resulted in littoral sediment translocation, reflected by worked off lacustrine sands.

Another, c. $20 \mathrm{~cm}$ thick peat section above shows maximum LOI values of c. $60 \%$ and consists of reed rhizoms in growing position within a black amorphic matrix. While an AMS sample provides a radiocarbon age of $9153 \pm 62 \mathrm{yr}$ BP (Preboreal), the pollen content reveals a forest composition of the Early Atlantic (Tab. 2, $174 \mathrm{~cm}$ depth), displayed by a dominant amount of Pinus, Alnus and Tilia. A second pollen sample at $164 \mathrm{~cm}$ depth holds a higher proportion of $\mathrm{NAP}$, while the arboreal pollen portion is dominated by $\mathrm{Pi}$ nus, Betula, Quercus and Alnus. Thus we assign this section to the Late Atlantic/Subboreal transition (Tab. 2).

The colluvium M1 (c. 1.50-1.30 m depth) consists predominantly of silt and in the range of the transition to the peat above of sand. Subordinated fine gravel and redeposited plant material (reeds) are included.

The overlying peat is partly mineralised at its base, but it is rich in wood remains and notable stones, gravel and sand in equal stratigraphic position. At c. $1.10 \mathrm{~m}$ depth there are single stray sands and several findings of municipal waste. Seventeen bones from sheep and goat and fragments of an elk have been recovered. A radiocarbon age of $2869 \pm 42 \mathrm{yr}$ BP dates the peat formation to the Subboreal. This age is proven by the archaeological context, which dates settle- ment activity at the surrounding and artefacts within the peat to the Late Bronze Age.

The colluvium M2 is characterised by redeposited plant material, sand and fine sediment fraction (clay, silt), while within exposure $\mathrm{KH}-2$ (C-D) fine and medium sand and also gravel could be detected. This indicates a gradual reduction of grain size from the catchment towards basin centre, possibly due to a lowering of transport capacity during run-off (AUERSWALD 1998).

The buried mineral horizon with high organic matter content reflects subsequent intermittent surface stability during wet conditions within the depression, emphasised by rather decomposed macrofossil remains of sedges. A radiocarbon age of $1699 \pm 41$ yr BP reveals an approximate time mark of layer formation.

Colluvial layer M3 is separated from colluvium M4 by a soil surface horizon (Ahb, IUSS WORKING GROUP WRB 2006). The pollen sample at $73 \mathrm{~cm}$ depth contains high values of NAP and cereals including Secale. While cereals diminish between $67-73 \mathrm{~cm}$ depth, weeds increase.

The buried soil surface horizon is related to the Younger Subatlantic (Middle Ages, Tab. 2). Both colluvial units show a grain size distribution dominated by fine and medium sands. The ploughed horizon at the surface (Ap, IUSS WorkING Group WRB 2006) reflects current agricultural use at the investigation site.

\section{Discussion}

The investigated depression can be classified as a glacigenic kettle-hole due to the record of a basal peat of Early Holocene age, which covers the glacial parent material (till) after meltout processes of stagnant ice during the 


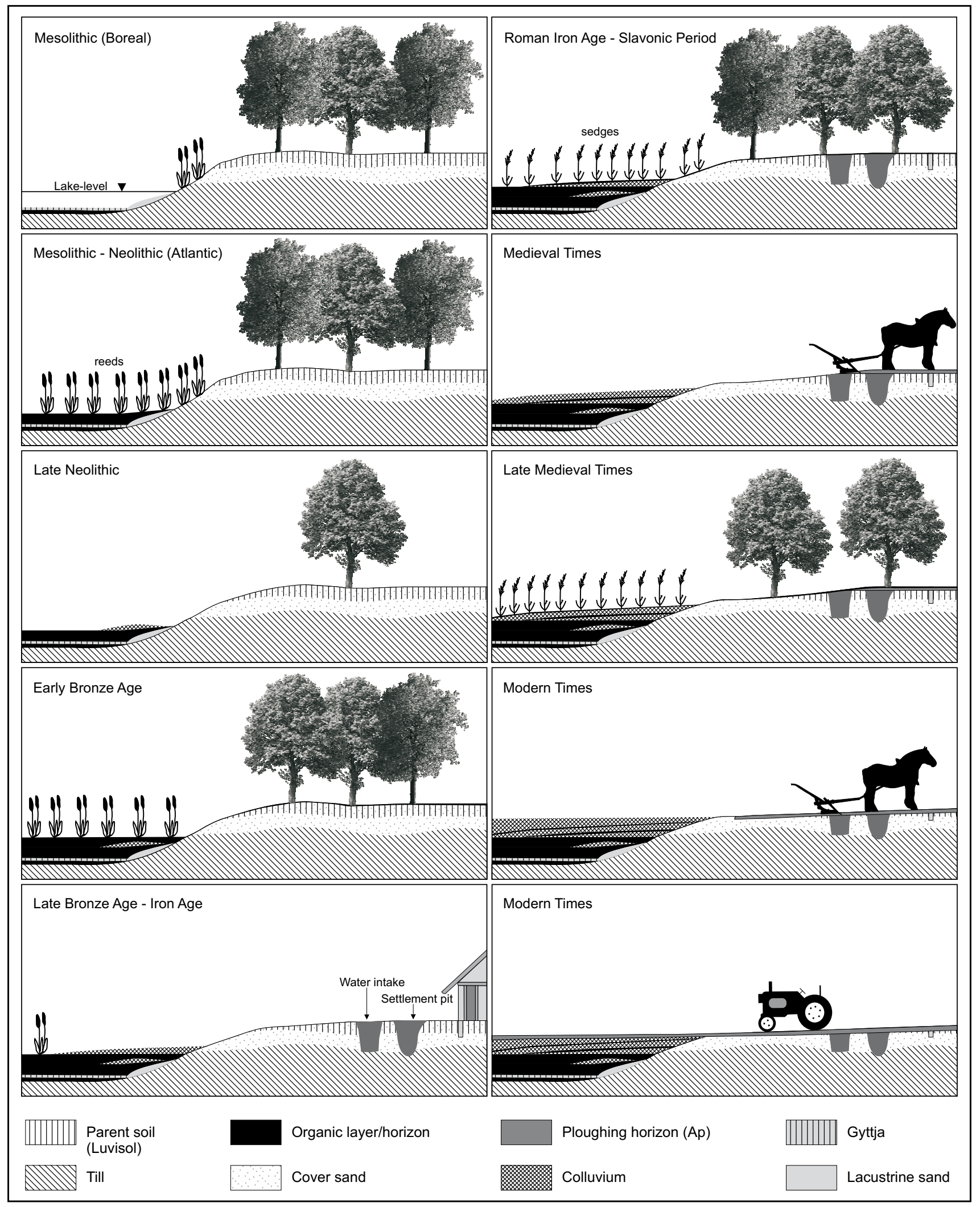

Fig. 4: Idealised model of Holocene landscape development and human impact at Kühlenhagen.

Abb. 4: Idealisiertes Modell zu holozäner Landschaftsentwicklung und menschlichem Einfluss bei Kühlenhagen.

Late Glacial period of the Weichselian glaciation (KLAFS, JESCHKE \& SCHMIDT 1973). The change from peat to gyttja points to the existence of an open intermediate and shallow lake (Fig. 4). An increase in the ground water and thus increased water filling into the small closed depression can be concluded for the Boreal. Palaeohydrological studies at various lakes in NE-Germany show similar trends of ris- ing lake-levels from the Boreal to the Mid-Atlantic (KAISER et al. 2003; LORENZ 2007; Küster 2009; LAMPE et al. 2009). The mineral sand peak (medium and coarse sand) at the gyttja-peat transition and the onset of peat formation itself reflect a shore displacement towards the lake basin due to a drop in lake-level and following aggradation (DigERFELDT 1986; Harrison or Digerfeldt 1993). The pollen values 
from the aggradational peat allow this to be clearly distinguished from the Boreal and put it in the Early Atlantic Period. Based on the palynological data, the obtained ${ }^{14} \mathrm{C}$-age (Erl-13815) from the peat can be regarded as too old possibly due to allochthonous input of older organic material and minerogenic matter during mean erosional processes. Slope erosion during the Early to Mid-Holocene is documented from various sites in Germany, summarised by Dreibrodt et al. (2010).

The accumulation of colluvium M1 shows a first prominant phase of anthropogenic influence in the study area. As a prerequisite for erosional input to the basin, forest clearing resulting in a partly exposed surface in the kettle-hole surroundings must be assumed. The peat above is AMSdated to the Late Subboreal. This age is proven by findings within the peat at the same depth and the archaeological context of the reconstructed settlement close to the kettlehole, set to the Late Bronze Age/Early Iron Age. The installation of the water intake close to the depression reflects the importance of water withdrawal for settlement activities during the aggradation process. Because of reconstructed rates of peat growing from regional sites from the Mid-Atlantic to the Subboreal of $0.1 \mathrm{~mm} / \mathrm{a}$ (KLOss 1987) and about $0.3 \mathrm{~mm} / \mathrm{a}$ during the Subboreal (LAmpE et al. 2009) and taking the palynological and radiocarbon datings into account, giving a maximum and minimum age of underlying and overlying peat, the accumulation of the colluvium M1 can be adopted for the Mid-Subboreal, the Late Neolithic Period in this region (EndTMAnn 2004). This period is proven within the study area by many single finds, while at least two places close to Kühlenhagen site can be indicated as small settlements (Ruchнӧғт 2009, Fig. 3). Therefore a geomorphic response on Neolithic human impact is assumed, however evidence of colluvial sediments of this period have not been discovered for the area of Vorpommern, exceptionally demonstrated by KAISER, ENDTMANN \& JANKE (2000) in a similar morphological situation in the south of the Darß-Zingst peninsula (southern Baltic coast). The human impact during the Neolitic is more significantly recorded in regional pollen sequences, reflecting secondary succession cycles on small previously agricultural fields (Kalis, Merkt $\mho$ Wunderlich 2003).

After accumulation of colluvium M2 an interim postsedimentary phase of surface stability occured reflected by the formation of a soil horizon of high organic content within the colluvial parent material under increased groundwater influence at least during the Roman Iron Age. The extracted ${ }^{14} \mathrm{C}$-age, Erl-13813, gives a minimum age of organic layer formation (LÜDERS 1961; LESSMANN-SCHOCH, KAHRER \& BRÜMMER 1991). Therefore a sedimentation period of the colluvium M2 between the Late Bronze Age and the Roman Iron Age can be traced.

Many settlements from the Younger Bronze Age up to the Roman Iron Age were discovered around Kühlenhagen in the last years. Some hundred meters in the south of the investigated depression a Germanic settlement with cemetery from the Late Roman Iron Age was detected (REINEKE 1988; RAuchfuss \& SCHMIDT 2004). Thus settlement activities from the Younger Bronze Age up to Late Roman Iron Age might be seen as a continual process, indicating that human activities at Kühlenhagen during this period were significant in prehistorical times, resulting in soil erosion processes.
The deposition of both colluvial sediment units on top leads to the final filling of the edge of the kettle-hole. The palynological data of the buried surface horizon indicate an approximate time frame from the Late Medieval to the Early Modern Era giving a maximum age of the colluvium M3, which thus comprises the Slavonic Period up to the German Medieval. Based on a few regional Slavonic findings, the mineral sediment influx is rather explained by soil erosion due to deforestation for areas of settlements and agricultural use during the Eastern Colonisation of the $13^{\text {th }}$ century AD. This is also recorded sedimentologically in adjacent areas in formation of aeolian drift sands (JANKE 1971).

The pollen samples from the buried Ahb horizon give evidence of intense human impact close to the kettle-hole due to forest clearing and subsequent extensive agricultural use. During the Modern Era up to the recent past, soil erosion leads to the final filling of the outer part of the depression up to the present level. Based on numerous colluvial records in adjacent till plains, this period appears to be the dominant historical erosion phase throughout Vorpommern (HelBig et al. 2002).

\section{Conclusions}

This study represents qualitative data of the Holocene landscape development in Vorpommern. Thereby geoarchaeological investigations at a glacigenic kettle-hole give sedimentary evidence of prehistorical and historical phases of soil erosion, reflecting human impact and geomorphological response at a till plain. The first sedimentological fingerprint of human impact at Kühlenhagen is reflected by colluvial sediments dated to the Late Neolithic. However, regional land use intensities were relatively low. An almost continuous settlement process within the investigation area occurred from the Late Bronze Age up to the Late Roman Iron Age. Land use and settlement activities at the transition from the Late Bronze Age to the Early Iron Age led to soil erosion. Taking the density of settlement finds into consideration one can assume that human impact during this prehistorical period was significant. After following moderate to low human influences up to the Slavonic Period, deforestation during the Eastern Colonisation in the $13^{\text {th }}$ century stripped the surface bare initialising a third phase of soil erosion ending in the Late Middle Ages, where an interim phase of surface stability could be reconstructed. Agriculture related soil erosion during the Modern Era led to a final silting of the kettle-hole.

\section{Acknowledgements}

We would like to thank Michael Naumann (Hannover) for his support during field work and Christina Hierath (Angermünde) for proofreading English. Finally we are grateful to two reviewers who gave us critical remarks and helpful advice for our manuscript.

\section{References}

Amelang, K., Janke, W. ひ Kliewe, H. (1983): Formenveränderungen und Substratumlagerungen an Grenzsäumen zwischen Naturraumeinheiten des Küstengebietes. - Wissenschaftliche Zeitschrift der ErnstMoritz-Arndt-Universität Greifswald, Mathematisch-naturwissenschaftliche Reihe, 32, 1/2: 81-92. 
Auerswald, K. (1998): Bodenerosion durch Wasser. - In: Richter, G. (ed.): Bodenerosion. Analyse und Bilanz eines Umweltproblems: 33-42; Darmstadt (Wissenschaftliche Buchgesellschaft).

Beug, H.-J. (2004): Leitfaden der Pollenbestimmung für Mitteleuropa und angrenzende Gebiete. - 542 S.; München (Pfeil).

Bork, H.-R. (2006): Landschaften der Erde unter dem Einfluss des Menschen. - 207 S.; Darmstadt (Primus Verlag).

Bork, H.-R. (1983): Die holozäne Relief- und Bodenentwicklung in Lössgebieten. - In: Bork, H.-R. \& Ricken, W. (eds.): Bodenerosion, holozäne und pleistozäne Bodenentwicklung: Soil erosion, Holocene and Pleistocene soil development: 1-93. Catena Supplement 3; Cremlingen.

Bork, H.-R., Bork, H., Dalchow, C., Faust, B., Piorr, H.-P. \& Schatz, T. (1998): Landschaftsentwicklung in Mitteleuropa. - 328 S.; Gotha (Klett-Perthes).

Digerfeldt, G. (1986): Studies on past lake-level fluctuations. - In: BERGLund, B.E. (ed.): Handbook of Holocene palaeoecology and palaeohydrology: 127-143; Chichester.

DotTerweich, M. (2005): High-resolution reconstruction of a 1300 year old gully system in northern Bavaria, Germany: a basis for modelling longterm human-induced landscape evolution. - The Holocene, 15, 7: 994-1005.

DotTerweich, M. (2008): The history of soil erosion and fluvial deposits in small catchments of central Europe: Deciphering the long-term interaction between humans and the environment - A review. - Geomorphology, 101: 192-208.

Dreibrodt, S., Lubos, C., Terhorst, B., Damm, B. \& Bork, H.-R. (2010): Historical soil erosion by water in Germany: Scales and archives, chronology, research perspectives. - Quaternary International, 222: 80-95.

EndTMAnN, E. (2004): Die spätglaziale und holozäne Vegetations- und Siedlungsgeschichte des östlichen Mecklenburg-Vorpommerns - Eine paläoökologische Studie. - Ph.D.-Thesis, University of Greifswald.

Firbas, F. (1949): Die spät- und nacheiszeitliche Waldgeschichte Mitteleuropas nördlich der Alpen. Bd. 1 Allgemeine Waldgeschichte. - 480 S.; Jena (Fischer)

GLA - Geologisches Landesamt Mecklenburg-Vorpommern (1996): Übersichtskarte Quartär 1:200.000, Blatt Stralsund, Schwerin.

Harrison, S. P. ¿ DigerfeldT, G. (1993): European lakes as palaeohydrological and palaeoclimatic indicators. - Quaternary Science Reviews, 12: $233-248$.

Helbig, H. (1999): Die periglaziäre Überprägung der Grundmoränenplatten in Vorpommern. - Petermanns Geographische Mitteilungen, 143, 5/6: 373-386.

Helbig, H., de Klerk, P., Kühn, P. \& Kwasniowski, J. (2002): Colluvial sequences on till plains in Vorpommern (NE-Germany). - Zeitschrift für Geomorphologie N.F., Suppl.-Bd., 128: 81-100.

Horst, F. (1963): Ausgrabungen auf dem früheisenzeitlichen Burgwall von Kamminke (Usedom), Kr. Wolgast, im Jahre 1962. - Ausgrabungen und Funde, 8: 186-191.

IUSS WORKING GROUP WRB (2006): World reference base for soil resource 2006. 2nd edition. World Soil Resources Reports No. 103. FAO, Rome.

JANKE, V. \& JANKE, W. (1970): Zur Entstehung und Verbreitung der Kleingewässer im nordmecklenburgischen Grundmoränenbereich. Archiv für Naturschutz und Landschaftsforschung, 10: 3-18.

JANKE, W. (1971): Beitrag zu Entstehung und Alter der Dünen der Lubminer Heide sowie der Peenemünde-Zinnowitzer Seesandebene. - Wissenschaftliche Zeitschrift der Ernst-Moritz-Arndt-Universität Greifswald, Mathematisch-naturwissenschaftliche Reihe, 20, 1/2: 39-54.

JANke, W. (1983): Natürliche Ausstattung, Nutzung und jüngere Landschaftsveränderungen im unteren Peenetal bei Anklam. - Wissenschaftliche Zeitschrift der Ernst-Moritz-Arndt-Universität Greifswald, Mathematisch-naturwissenschaftliche Reihe, 32, 1/2: 57-69.

KAISER, K. \& JANKE, W. (1998): Bodenkundlich-geomorphologische und paläobotanische Untersuchungen im Ryckbecken bei Greifswald. Bodendenkmalpflege in Mecklenburg-Vorpommern, 45: 69-102.

Kaiser, K., Bogen, C., Czakó-Pap, S. \& Janke, W. (2003): Zur Geoarchäologie des mesolithisch-neolithischen Fundplatzes Rothenklempenow am Latzigsee in der Ueckermünder Heide (Vorpommern). Greifswalder Geographische Arbeiten, 29: 27-68.

Kaiser, K., Endtmann, E. \& Janke, W. (2000): Befunde zur Relief-, Vegetations- und Nutzungsgeschichte in Ackersöllen bei Barth, Lkr. Nordvorpommern. - Bodendenkmalpflege in Mecklenburg-Vorpommern 47: $151-180$

Kaiser, K., Schoknecht, T., Janke, W., Kloss, K. \& Prehn, B. (2002): Geomorphologische, palynologische und archäologische Beiträge zur holozänen Landschaftsgeschichte im Müritzgebiet (Mecklenburg-Vorpommern). - Eiszeitalter und Gegenwart, 51: 15-32.

Kalis, A.-J., Merkt, J. \& Wunderlich, J. (2003): Environmental changes during the Holocene climatic optimum in central Europe - human im- pact and natural causes. - Quaternary Science Reviews, 22: 33-79.

Klafs, G., JeschKe, L. \& Schmidt, H. (1973): Genese und Systematik wasserführender Ackerhohlformen in den Nordbezirken der DDR. Archiv für Naturschutz und Landschaftsforschung, 13: 287-302.

Kliewe, H. (2004). Weichsel-Spätglazial. - In: KatzunG, G. (ed.): Geologie von Mecklenburg-Vorpommern: 242-251; Stuttgart (Schweizerbart).

KLoss, K. (1987): Zur Genese von Niederungsmooren. - Wissenschaftliche Zeitschrift der Ernst-Moritz-Arndt-Universität Greifswald, Mathematisch-naturwissenschaftliche Reihe, 36, 1/2: 52-54.

Küster, M. (2009): Holozäne Bodenerosion und Paläohydrologie im Sander des Pommerschen Stadiums bei Blankenförde (MecklenburgStrelitz). - Diploma-Thesis. University of Greifswald.

Lampe, R., Lorenz, S., Janke, W., Meyer, H., Küster, M., Hübener, T. Schwarz, A. (2009): Zur Landschafts- und Gewässergeschichte der Müritz. Umweltgeschichtlich orientierte Bohrungen 2004-2006 zur Rekonstruktion der nacheiszeitlichen Entwicklung. - In: NATIONALPARKAMT MÜRITZ (ed.): Forschung und Monitoring, vol. 2; Greifswald (Geozon).

LAMPE, W. (1981): Zur endbronzezeitlichen Besiedlung der Insel Usedom. - Bodendenkmalpflege in Mecklenburg, Jahrbuch 1981: 84-114.

LAMPE, W. (1989): Jungbronzezeitliche Fundkomplexe mit Kleinbronzen. Ausgrabungen und Funde, 34: 119-129.

Lessmann-Schoch, U., Kahrer, R. \& Brümmer, G.W. (1991): Pollenanalytische und ${ }^{14} \mathrm{C}$-Untersuchungen zur Datierung der Kolluvienbildung in einer lößbedeckten Mittelgebirgslandschaft (Nördlicher Siebengebirgsrand). - Eiszeitalter und Gegenwart, 41: 16-25.

LoRENZ, S. (2007): Die spätpleistozäne und holozäne Gewässernetzentwicklung im Bereich der Pommerschen Haupteisrandlage Mecklenburgs. - Ph.D.-Thesis, University of Greifswald.

LÜDERS, R. (1961): Altersbestimmung an einem doppelten Podsolprofil aus dem Emsland. - Zeitschrift für Pflanzenernährung, Düngung, Boden kunde, 94: 47-53.

Mangerud, J., Andersen, S. T., Berglund, B. E. ひ Donner, J. J. (1974): Quaternary stratigraphy of Norden, a proposal for terminology and classification. - Boreas, 3: 109-128

NilleR, H.-P. (1998): Prähistorische Landschaften im Lößgebiet bei Regensburg. - Regensburger Geographische Schriften 31.

RAUCHFuß, B. \& SchmidT, J.-P. (2004): Neue Gräber der jüngeren vorrömischen Eisenzeit aus Netzeband, Lkr. Ostvorpommern. - Bodendenkmalpflege in Mecklenburg-Vorpommern, 52: 295-321.

ReINECKE, A. (1988): Studien zur vorrömischen Eisenzeit im Umland der südlichen Ostsee. Forschungsstand - Chronologie - Kulturhistorische Beziehungen.-Ethnographisch-ArchäologischeZeitschrift,21:129-146.

Reiß, S., Dreibrodt, S., Lubos, C.C.M. \& Bork, H.-R. (2009): Land-use and historical soil erosion at Albersdorf (northern Germany) - Ceased agricultural land use after the pre-historical period. - Catena, 77: 107-118.

Ruchнӧғт, F. (2009): Archäologische Ausgrabungen im Verlauf der Ostseepipelineanschlussleitung (OPAL) in Mecklenburg-Vorpommern. unveröfft. Grabungsbericht zur Hauptuntersuchung in Kühlenhagen, Lkr. Ostvorpommern, Fpl. 7 (OPAL-Nr. 18). Landesamt für Kultur und Denkmalpflege, Abt. Archäologie und Denkmalpflege. Schwerin.

RüHberg, N., SchulZ, W., von Bülow, W., MÜller, U., KrIENKe, H.-D., BreMER, F. \& DANN, T. (1996): Mecklenburg-Vorpommern. - In: BENDA, L. (ed.) Das Quartär Deutschlands: 95-115; Berlin, Stuttgart (Borntraeger)

SснміDт, J.-P. (2006): Die jungbronzezeitliche Siedlung von Gützkow, Lkr Ostvorpommern - Ein Beitrag zu bronzezeitlichen Hausbefunden aus Mecklenburg-Vorpommern. - Bodendenkmalpflege in Mecklenburg Vorpommern, 54: 11-52

SchокNECHT, U. (1978): Jungbronzezeitliche und ältereisenzeitliche Siedlungsgruben bei Waren/Müritz. - Bodendenkmalpflege in Mecklenburg-Vorpommern. Jahrbuch 1978: 115-132.

STARKEL, L. (2005): Role of climatic and anthropogenic factors accelerating soil erosion and fluvial activity in Central Europe. - Studia Quaternaria, 22: 27-33.

Stuiver, M., Reimer, P. J. \& Reimer, R. W. (2005). CALIB 5.0.1 [WWW program and documentation].

SzCZESIAK, R. (1999): Eine bemerkenswerte frühbronzezeitliche Siedlung bei Neuenkirchen, Landkreis Mecklenburg-Strelitz. - In: BudEsHeıM, W. \& KeILING, H. (eds.): Zur Bronzezeit in Norddeutschland: 107-122. Beiträge für Wissenschaft und Kultur, 3; Freie Lauenburgische Akademie für Wissenschaft und Kultur; Neumünster.

WiLKInson, K.N. (2003): Colluvial deposits in dry valleys of southern England as proxy indicators of palaeoenvironmental and land-use change. - Geoarchaeology, 18: 725-755.

ZolitschKa, B, Behre, K.-E. \& Schneider, J. (2003): Human and climate impact on the environment as derived from colluvial, fluvial and lacus trine archives - examples from the Bronze Age to the Migration period, Germany. - Quaternary Science Reviews, 22: 81-100. 